ELORE (ISSN 1456-3010), vol. 20 - 1/2013.

Julkaisija: Suomen Kansantietouden Tutkijain Seura ry.

[http://www.elore.fi/arkisto/1_13/huuskonen.pdf]

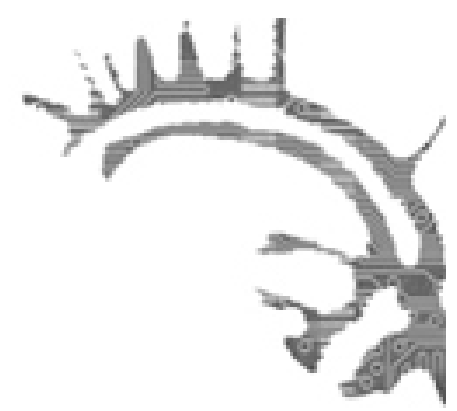

\title{
LECTIO
}

\section{VAIETUT HISTORIAT JA PERINTEET}

\author{
$\underline{\text { Kari Huuskonen }}$
}

Lectio praecursoria Helsingin yliopistossa 18.1.2013

Vanhan sanonnan mukaan Minervan pöllö nousee lentoon vasta hämärän laskeutuessa. Taustalla on ajatus, että jotakin historiallista aikakautta voidaan ymmärtää vasta, kun se on päättynyt; kun aurinko on laskeutunut ja jotakin peruuttamatonta on jäänyt taakse.

Toisaalta historian on sanottu olevan päättymätön prosessi. Historia kirjoitetaan joiltakin osin aina uudelleen, kun nykyisyydessä tapahtuu jotakin olennaista. Jokainen sukupolvi katselee menneisyyttä oman aikakautensa arvostusten, ihanteiden ja argumentaatioiden valossa. Tässä mielessä historia on kuin avoin kertomus vailla varmuutta sulkeutuvasta lopusta. Sille ei ole löydettävissä yhtä yhtenäistä juonellista rakennetta. Menneisyys koostuu joukosta erilaisia tapahtumia, sattumanvaraisuuksia ja paradokseja, joista jotkut hyväksytään yhteiseen kulttuuriseen kuvastoomme, ja joihin tiivistyy helposti koko aikakauden välittämä ajankuva.

Monet nykyiset historian, kulttuurin, perinteen ja kirjallisuuden tutkijat lähestyvät menneisyyttä koskevia kysymyksiä moniulotteisesti. Historiallisia aikakausia ei nähdä enää pelkästään tutkimuskohteina, vaan eri aikakaudet muodostavat itsessään tärkeitä metodisia työkaluja silloin, kun erilaisille tietolähteille halutaan esittää niiden syntyhistoriaa koskevia kysymyksiä. Tällaisia tietolähteitä ilmentävät esimerkiksi muistitietoaineistot. Niiden erityispiirteenä on se, että muistitieto kertoo enemmän menneisyyden tapahtumille annetuista merkityksistä kuin itse tapahtumista, kuten italialainen muistitiedon ja kirjallisuuden tutkija Alessandro Portelli on esittänyt. Portellin mukaan muistitietoa läh- 
teenään käyttävän tutkijan kannalta olennaista ei niinkään ole kysyä sitä, mitä tarkalleen ottaen joskus menneisyydessä on tapahtunut vaan millaisia tulkintoja näihin tapahtumiin liitetään niitä muisteltaessa. Tällä tavoin kysyttäessä menneisyyteen suuntautuva mielenkiinto voi avartua samanaikaisesti myös nykyisyyteen ja tulevaisuuteen suuntautuvasti. Mielenkiinnon kohteeksi voi nousta se, miksi jotkin tietyt historialliset tapahtumat tai kokemukset nousevat kerronnan kohteeksi tietyllä tavalla tiettyyn aikaan. Miten käytämme historiaa nykyisyyteen ja tulevaisuuteen ulottuvien arvovalintojen tukena?

Jokaisella aikakaudella, vuosikymmenellä ja sukupolvella on omat äänensä ja kasvonsa julkisuudessa. Näille historioille ja julkisuuksille on kuitenkin leimallista se, että niistä harvoin välittyy vähemmistöryhmien ja -kulttuurien edustajien näkökulmat. Tästä ovat hyvänä esimerkkinä eri tavoin vammaisiksi luokitellut kansalaiset, joiden osana on ollut esiintyä historian lehdillä lähinnä passiivisessa roolissa väheksynnän ja huoltotoimenpiteiden kohteina. Syynä tällaiseen näkökulman vinoumaan on ensiksikin se, että tavalla tai toisella vammautuneiden ihmisten tavallinen arki ei ole jättänyt arkistoihin tutkijoille johtolankoja samalla tavalla kuin valtiolliset tapahtumat tai hallitsijoiden toimenpiteet. Toiseksi valtaosa vammaisiin kohdistuneen historiantutkimuksen käyttämistä lähteistä on syntynyt viranomaisten harjoittaman valvonnan, huollon, hoidon ja opetuksen seurauksena. Vammaiset ovat harvoin päässeet valikoimaan niitä tietoja, joita heistä on asiakirjoihin ja dokumentteihin merkitty. Monet viime vuosikymmeninä kerätyt vammaisten elämäkerrat ja vammaisjärjestöjen tuottamat aineistot puhuvat kuitenkin vammaisten kansalaisten passiivista olemassaoloa vastaan. Näiden aineistojen hyödyntäminen akateemisissa tutkimuksissa ja opinnäytetöissä olisikin tärkeää. Vaietut historiat ja perinteet eivät avaudu virallisista asiakirjoista vaan nimenomaan muistitiedon ja muiden henkilökohtaisten lähteiden avulla.

Miten tällaisia aineistoja sitten tulisi lähestyä metodologisesti? Millaisiin asioihin tutkijoiden tulee kiinnittää huomiota, jotta vaietut historiat ja perinteet saadaan näkyviin ja kuuluviin? Tämä on sellainen kysymys, josta muistitietotutkimuksen piirissä on keskusteltu pitkään, mutta joka on vammaishistorian piirissä vasta alullaan. Tarkoitan tällä sitä, että tutkimusaineistoille voidaan esittää monenlaisia kysymyksiä, jotka voivat tuoda esiin hyvin erilaisia ja jopa keskenään ristiriitaisia tulkintoja. Kukaan tutkija ei lähesty menneisyyttä koskevia kysymyksiä täysin viattomana. Tutkimuksen lähtökohdat ja tavoitteet vaikuttavat aina saatuihin tuloksiin. Kysymys on viime kädessä siitä, mitä kaikkea hyväksymme käytettävissä olevasta kertomusaineksesta kerrottavaan tarinaan ja millä perusteella.

Historiaa on joskus luonnehdittu ihmisen onnettomuutta tutkivaksi tieteeksi. Tämä on yksi tapa problematisoida vammaishistoriaa koskevia kysymyksiä. Toinen ja valoisampi lähestymistapa on kiinnittää huomiota niihin erilaisiin selviytymisstrategioihin, joilla vammaiset ihmiset ovat historian eri tilanteissa kohdanneet elämisen haasteet ja selviytyneet niistä. Näiden lisäksi kolmantena mahdollisuutena on myös luopua jokotai-vastakkainasetteluista ja esittää asioiden olevan sekä-että.

Tutkimukseni keskeinen käsite modernisaatio viittaa länsimaisesta ja etenkin suomalaisesta perspektiivistä katsoen ajallisesti suhteellisen pitkään yhtenäiseen ajanjaksoon: sen voidaan sanoa alkaneen noin 1860-luvulta ja päättyneen 1960-luvulle. Tähän ajanjaksoon on sisältynyt monia suurempia ja pienempiä yhteiskunnallisia ja kulttuurisia 
murroksia, jotka sitovat eri sukupolvet omaan historialliseen kokemustaustaan. Ajanjakson puitteisiin mahtuvat niin 1860-luvun lopun suuret nälkävuodet kuin 1900-luvulla koetut ensimmäinen ja toinen maailmansotakin. Modernisaatiota on kuvattu myös agraariyhteiskunnan hajoamiseksi, teolliseksi vallankumoukseksi, sääty-yhteiskunnan murenemiseksi ja kansalaisyhteiskunnan muotoutumiseksi sen mukaan, mitä piirteitä modernisaatiosta on kulloinkin haluttu korostaa. Käytetyt vertaukset ovat myös kasvaneet ajan saatossa suomalaisen yhteiskunnan lähihistorian kuvaksi ja modernisaation keskeisiksi tunnusmerkeiksi.

Nykysuomen etymologisen sanakirjan mukaan termi moderni tulee latinan sanasta modernius. Se omaksuttiin suomen kieleen 1800-luvulla tarkoittamaan samaa asiaa kuin uudenaikainen, nykyaikainen tai muodikas. Sen vastakohdaksi on sittemmin muotoutunut modernisaatiota käsittelevässä tutkimuskirjallisuudessa traditionaalinen tai esimoderni. Näiden vastaparien avulla on pyritty kuvaamaan murroksia, siirtymisiä ja muutosta vanhasta uuteen. Tähän muutosprosessiin on sisältynyt myös vahvoja olettamuksia vanhojen traditioiden väistymisestä uusien tieltä. Monet viimeaikaiset tutkijat historian, etnologian ja folkloristiikan piirissä ovat kuitenkin tuoneet esiin havaintojaan siitä, ettei modernisaatiota voida kuvata yhtenä suurena voimana, joka olisi jyrännyt alleen kaikki tielleen osuneet perinteen muodot. Se on pikemminkin edistynyt pienten, päivittäisten kokeilujen ja ympäristöstä poimittujen havaintojen avulla, kuten esimerkiksi vuonna 2006 ilmestyneen kokoomateoksen Modernisaatio ja kansan kokemus artikkelit kiinnostavasti osoittavat.

Tutkimuksessani lähestyn modernisaatiota sekä pidemmällä että lyhyemmällä aikavälillä keskittyen kuitenkin pääsääntöisesti 1800-luvun lopun ja 1900-luvun alkuvuosikymmenien väliseen ajanjaksoon. Tällöin syntyi Suomeen ensimmäinen koulutettu näkövammaisten ikäpolvi, joka omaksui yhdistysaatteen yhteisöllisen toimintakulttuurin malliksi. Kutsun heitä työssäni näkövammaisten ensimmäiseksi järjestäytyneeksi sukupolveksi. Heitä kaikkia yhdisti yhteisenä avainkokemuksena sokeainkoulu. Kun näkövamma oli sekä heille että myös heidän jälkeensä tulleille sukupolville ensisijainen koulutusta ja ammatinvalintaa määrittävä kriteeri, yhteisön ja yhteiskunnan jäseniksi kasvettiin sukupolvi toisensa perään omien koulujen ja työlaitosten kautta.

Näkövammaisten yhteisön eristyneisyys, mutta toisaalta aktiivinen pyrkimys suuntautua ulospäin ovat synnyttäneet ja jättäneet arkistoihin poikkeuksellisen kiinnostavan kirjallisen ja muistitietoon pohjautuvan suullisen aineiston. Varhaisimmat käytettävissä olevat lähteeni ovat syntyneet samoihin aikoihin suomalaisen kansallisen julkisuusinstituution rakentumisen kanssa. Näihin aineistoihin kuuluvat sekä päälähteenä käyttämäni sokeainlehdet että sokeainyhdistysten pöytäkirjat. Niitä täydentävät elämäkerralliset haastattelut, joiden vanhimmat kertojat ovat olleet perustamassa ensimmäisiä omia sokeainyhdistyksiä ja -lehtiä Suomeen viime vuosisadan alussa.

Tutkimukseni tavoitteena on ollut tuoda nämä aineistot ja niiden välittämät menneisyyden ajatusmaailmat ja kokemukset osaksi akateemisessa vammaistutkimuksessa ajankohtaista keskustelua modernisaation suhteesta vammaisuuteen. Tutkimuksessani tätä suhdetta ilmentävät muiden muassa kysymykset siitä, mitkä tai millaiset modernisaatiota ilmentävät yhteiskunnalliset muutokset ja uudelleenjärjestelyt ovat edistäneet näkövammaisten kansalaisten osallistumisen mahdollisuuksia yhteiskunnassa, mitkä sen sijaan eivät. 
Tutkimukseni perusteella näkövammaisten ensimmäisten järjestäytyneiden sukupolvien modernisaatiokokemukset voidaan palauttaa ainakin kolmenlaisiin kokemustaustoihin. Ensimmäinen kokemusten säie kietoutuu uskonnollisen ja tieteellisen maailmankuvan murrokseen. Darwinismin ja luonnontieteellisen maailmankatsomuksen astuttua kuvaan 1800-luvun lopulta käsitykset ihmisen asemasta ja paikasta osana Jumalan luomakuntaa alkoivat muuttua. Toisaalta uskonnollinen ajattelu ja siihen perustuvat maailman ja todellisuuden selitysmallit säilyttivät asemansa ihmisten arkiajattelussa tämänkin jälkeen. Tässä mielessä monet traditionaalisessa yhteiskunnassa vallinneet ajattelun rakenteet vain siirtyivät ja sopeutuivat osaksi modernin yhteiskunnan rakenteita.

Toinen tärkeä kokemusten säie kietoutuu suullisen ja kirjallisen kulttuurin murrokseen. Monet 1800-luvun lopulla ja 1900-luvun alkuvuosikymmeninä koetut ongelmat ja elämisen haasteet olivat jo traditionaalisessa yhteiskunnassa ilmenneitä ongelmia. Modernin yhteiskunnan myötä syntyneet uudenlaiset julkisuusfoorumit avasivat kuitenkin aivan uudenlaiset mahdollisuudet jakaa ja käsitellä näitä kokemuksia lähiyhteisöä laajemman sosiaalisen yhteisön tai verkoston kanssa kirjeenvaihdon ja lehtien välityksellä.

Kolmannen säikeen modernisaatiokokemusten taustaymmärryksessä tuovat esille yhteiskunnan taloudelliset, juridiset ja aatteelliset uudelleenjärjestelyt, jotka alkoivat määrätä 1900-luvun puolelle siirryttäessä yhä enemmän tavallisten kansalaisten elämää. Yhteiskunnan modernisoituminen eteni etenkin teollisuuden ja kaupan alalla nopeammin kuin siihen pystyttiin käsityöläisten piirissä sopeutumaan. Teollinen rakennemuutos toi mukanaan monia uudenlaisia taloudelliseen kilpailuun ja toimeentuloon liittyviä haasteita, jotka muokkasivat maaperää uhrimielialoille. Näitä uhrimielialoja ruokkivat lisäksi köyhäinhoidon tiukat säädökset ja perinnöllisyystieteen vanavedessä syntynyt rotuhygienialiike. Kaiken tämän ohessa ihmisten elämää varjostivat yhä heikkoon sosiaaliturvaan, sairauksiin ja korkeaan kuolleisuuteen liittyvät yhteiskuntarakenteen kehittymättömyydestä johtuvat ongelmat. Ne tekivät ihmisten elämän monella tapaa turvattomaksi.

Toisaalta on kiinnostavaa, että tällaiset turvattomuuden kokemukset ja uhrimielialat kyettiin myös kääntämään aktiiviseksi vastarinnaksi. Ajatus modernista yhteiskunnasta ja kansalaisuudesta hajotti traditionaalisen yhteiskunnan pakkoyhteisöllisyyden ja loi edellytykset individualismin synnylle, joka ideaalimuodossaan tarkoitti sitä, että myös yksilöt pystyivät toiminnallaan muuttamaan maailmanjärjestystä ja murtautumaan ulos köyhyyden ja epätoivon kierteestä.

Tutkimusprosessini aikana olen tullut vakuuttuneeksi siitä, että yhteiskunnassa on ollut monia osallistumisen ja vaikuttamisen alueita, joissa näkövammaiset ovat pystyneet toimimaan ja asettamaan ehtoja vallitsevalle yhteiskunnalliselle ja sosiaaliselle todellisuudelle. Suppeimmillaan se on saattanut tarkoittaa vain alistumista ja sopeutumista omaan kohtaloon, mutta tutkimuksessani olen tuonut näkyviin esimerkkejä, joissa yksilöt ja ryhmät ovat pyrkineet toiminnallaan myös vaikuttamaan aktiivisesti oman kohtalonsa muotoutumiseen. Silmäys näihin esimerkkeihin osoittaa, että näkövammaisten ensimmäiset järjestäytyneet käsityöläis- ja hierojasukupolvet vastasivat modernisaation haasteeseen rationalisoimalla omia työskentelytapojaan, perustamalla käsityötuotteiden myymäläverkostoja ja hierontalaitoksia, rakentamalla neuvotteluyhteyksiä lainsäätäjiin ja ottamalla lainsäädäntöä ja sosiaalisia reformeja kehittävän järjestötyön hyväntekeväi- 
Kari Huuskonen: Vaietut historiat ja perinteet

syysyhdistyksiltä omiin käsiinsä. Kaikilla näillä menneisyydessä koetuilla tapahtumilla on oma merkityksensä sokeainyhteisön historiankerronnassa. Niiden kautta yhteisö on voinut rakentaa omanarvontuntoa ja itsekunnioitusta edistävää kertomusta itselleen.

\section{KirJallisuUs}

HUUSKONEN, KARI 2012: Pimeyden puolelta. Modernisaation kokemuksetnäkövammaisten kerrontayhteisössä. Helsingin yliopisto, folkloristiikka. Väitöskirja saatavilla elektronisena.

KIRJALLISUUS:

BORSAY, ANNE 2005: Disability and social policy in Britain since 1750 - A History of Exclusion. New York: Palgrave Macmillan.

BRADDOCK, DAVID L. \& PARISH, SUSAN L. 2001: An Institutional History of Disability. - Gary L. Albrecht, Katherine D. Seelman \& Michael Bury (eds.), Handbook of disability studies. Sage Publications.

HARJULA, MINNA 1996: Vaillinaisuudella vaivatut. Vammaisuuden tulkinnat suomalaisessa huoltokeskustelussa 1800-luvun lopulta 1930-luvun lopulle. Helsinki: Suomen Historiallinen Seura.

NIEMINEN, HANNU 2006: Kansa seisoi loitompana - kansallisen julkisuuden rakentuminen Suomessa 1809-1917. Tampere: Vastapaino.

NYGÅRD, TOIVO 1998: Erilaisten historia. Marginaalirybmät Suomessa 1800-luvulla ja 1900-luvun alussa. Jyväskylä.

PELTONEN, ULLA-MAIJA 2006: Muistitieto folkloristiikassa. - Outi Fingerroos, Riitta Haanpää, Anne Heimo \& Ulla-Maija Peltonen (toim.), Muistitietotutkimus. Metodologisia kysymyksiä. Helsinki: SKS.

PELTONEN, ULLA-MAIJA 2009: Rajaton kokemus - näkökulmia toiseen tietoon. Kati Launis \& Marko Tikka (toim.), Työväkija kokemus. Tampere: Työväen historian ja perinteen tutkimuksen seura.

PORTELLI, ALESSANDRO 2006: Mikä tekee muistitietotutkimuksesta erityisen. - Outi Fingerroos, Riitta Haanpää, Anne Heimo \& Ulla-Maija Peltonen (toim.), Muistitietotutkimus. Metodologisia kysymyksiä. Helsinki: SKS.

STARK, LAURA 2006a: Pitkospuilta modernisaation suolle. - Hilkka Helsti, Laura Stark \& Saara Tuomaala (toim.), Modernisaatio ja kansankokemus Suomessa 1860-1960. Helsinki: SKS.

STARK, LAURA 2006b: Kansallinen herääminen ja sosiaalinen nousu maaseudulla: tuskaa ja toivoa varhaisissa omaelämäkerroissa. - Hilkka Helsti, Laura Stark \& Saara Tuomaala (toim.), Modernisaatio ja kansankokemus Suomessa 1860-1960. Helsinki: SKS.

FT Kari Huuskonen työskentelee museoamanuenssina Näkövammaisten Keskusliiton ylläpitämässä Näkövammaismuseossa Helsingissä. 